\title{
Hypoglycaemia in an inner-city accident and emergency department: a 12-month survey
}

\author{
M. D. FEHER, P. GROUT, A. KENNEDY, R. S. ELKELES \& \\ R. TOUQUET
}

Departments of Clinical Pharmacology, Clinical Endocrinology and Accident and Emergency, St Mary's Hospital, London, England

\section{SUMMARY}

In a 12-month survey on the causes and frequency of hypoglycaemia presenting to an inner-city accident and emergency department, a total of $\mathbf{8 6}$ cases were recorded. A missed meal and/or alcohol ingestion accounted for most of the precipitating causes, being $52 \%$ and $21 \%$ respectively. As $49 \%$ of subjects presented with major clinical manifestations of hypoglycaemia (fit or coma), greater emphasis is required in the instruction on regularity of meal and caution with alcohol in high-risk groups such as the diabetic and also in non-diabetic groups.

\section{INTRODUCTION}

Whilst the consequences of untreated hypoglycaemia are well documented (Auer, 1986) the true frequency of presentation of hypoglycaemia for both diabetic and non-diabetic subjects is still unclear. Reasons for this uncertainty may be due to one of several of the following; the numerous precipitating factors; the protean clinical features and the varied location of presentation and treatment such as hospital, general practice or home. Differences between urban and rural populations may also be a factor. A study in innercity London would reflect the demographic qualities of a city population and might assist in the management of this particular clinical problem presenting to an accident and emergency department. We therefore set up a study to ascertain the causes, and also the frequency of presentation, of hypoglycaemia in all subjects presenting to an innercity accident and emergency department over a 12-month period.

Correspondence: Dr M. D. Feher, Departments of Clinical Pharmacology, St Mary's Hospital, London W2 1 NY, England. 


\section{METHODS}

St Mary's Hospital is a teaching hospital situated in West London where the Accident $\stackrel{\text { }}{\stackrel{2}{\circ}}$ and Emergency (A\&E) Department receives 47500 new patients per year. The patients $\Rightarrow$ in the study attended the A\&E department over a 12-month period from September $\frac{05}{6}$ 1986 to August 1987. All patients presenting with symptoms suggestive of hypogly- $\frac{\square}{\circ}$ caemia and/or an altered state of consciousness, had a blood glucose determined. Each $\frac{\overline{\bar{m}}}{\bar{s}}$ episode was documented by a standardized questionnaire, as well as a record entered in $\stackrel{\varnothing}{\varrho}$ the hospital notes. Details obtained included current illnesses and treatment, past medical history, previous hypoglycaemic episodes, details of alcohol/drug ingestion $\overrightarrow{0}$ over the preceding $24 \mathrm{~h}$ and the probable causes of hypoglycaemia which were classified $\overrightarrow{.}$ as one or several of the following; missed meal, increase in exercise, increase in insulin ${ }_{\stackrel{\leftrightarrow}{\omega}}$ dose, alcohol or drug ingestion or cause unknown. A blood glucose concentration was $\frac{\Phi}{\beta}$ determined by Gluco-stix and in over $90 \%$ of cases a venous blood sample (glucose $\frac{\text {. }}{-}$. oxidase method) confirmed the result. Hypoglycaemia was defined as a blood glucose of $\omega$ $3 \mathrm{mmol} / 1$ or less. When the history suggested alcohol excess, a venous blood alcohol $\overrightarrow{\mathrm{c}}$ concentration was determined using an Abbot TDX REA Ethanol method which has a lower limit of detection of $10 \mathrm{mg} \%$.

The departmental register was reviewed daily with the aim of picking up any missed $\mathscr{\Phi}_{\mathbb{D}}$ subjects and we consider few if any cases were missed. After appropriate treatment of $\frac{\mathbb{O}}{\stackrel{\circ}{\circ}}$ the hypoglycaemic episode a record was made detailing whether the patient was sent $\stackrel{\vec{\sigma}}{\mathrm{G}}$ home, referred to the general practitioner, diabetic clinic, diabetic liaison sister or was $\stackrel{\Phi}{-}$ admitted to the ward.

\section{RESULTS}

Over the 12 -month period of the study 86 hypoglycaemic episodes were recorded $\stackrel{2}{\Rightarrow}$ (Table 1), making up $0 \cdot 18 \%$ of the 47500 patients attending the A\&E department. The 3 total number of individual subjects presenting with hypoglycaemia was 72 ; this included 61 with insulin-dependent diabetes, three with non-insulin-dependent diabetes and eight subjects with no history of diabetes. All subjects $(n=8)$ who had $\frac{\Phi}{3}$ presented with more than one episode of hypoglycaemia had insulin-dependent diabetes. The mean duration of diabetes in the subjects with single or multiple 3 . hypoglycaemic episodes was 16.3 and 21.5 years respectively. The monthly frequency of case presentation with hypoglycaemia over the year indicated an increase in the summer months (Table 2).

In the insulin-dependent diabetic (IDD) subjects $54 \%$ had a history of a missed meal, $\frac{\vec{O}}{\mathrm{O}}$ $19 \%$ a history of recent alcohol ingestion, $12 \%$ an increase in exercise, while $17 \%$ had an increase in insulin dosage, as precipitating factors for hypoglycaemia (Table 3). In $N$ one case renal failure was thought to be the causal factor. There were no cases of 0 intentional insulin overdose.

In the three non-insulin-dependent diabetic (NIDD) subjects, all who were treated ${ }^{\circ}$

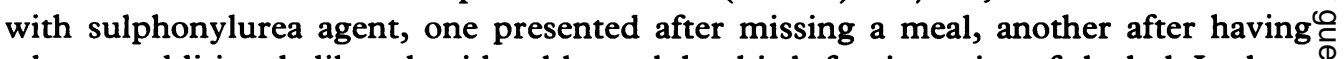
taken an additional glibenclamide tablet and the third after ingestion of alcohol. In three $\stackrel{\oplus}{\oplus}$ 
Table 1 Numbers and frequency of precipitating cases of hypoglycaemia

\begin{tabular}{|c|c|c|c|}
\hline & $\begin{array}{l}\text { Insulin- } \\
\text { dependent } \\
\text { diabetic }\end{array}$ & $\begin{array}{l}\text { Non-insulin- } \\
\text { dependent } \\
\text { diabetic }\end{array}$ & $\begin{array}{l}\text { Non- } \\
\text { diabetic }\end{array}$ \\
\hline Number of cases & 75 & 3 & 8 \\
\hline Mean age in years (range) & $43(8-53)$ & $44(32-51)$ & $57(29-81)$ \\
\hline Missed meal & $41(51 \%)$ & 1 & $3(38 \%)$ \\
\hline Alcohol & $14(19 \%)$ & 1 & $4(50 \%)$ \\
\hline $\begin{array}{l}\text { Increase in } \\
\text { insulin dose }\end{array}$ & $13(17 \%)$ & - & - \\
\hline $\begin{array}{l}\text { Increase in } \\
\text { exercise }\end{array}$ & $9(12 \%)$ & - & - \\
\hline Drugs & (Propranolol) 1 & (Glibenclamide) 1 & (Metoprolol) 1 \\
\hline Renal failure & 1 & - & - \\
\hline Not known & $14(19 \%)$ & - & $2(25 \%)$ \\
\hline
\end{tabular}

Table 2 Hypoglycaemic episodes per month

\begin{tabular}{ll}
\hline Number & Date \\
\hline 3 & September 1986 \\
6 & October \\
4 & November \\
3 & December \\
4 & January 1987 \\
8 & February \\
7 & March \\
7 & April \\
7 & May \\
5 & June \\
15 & July \\
17 & August 1987 \\
\hline
\end{tabular}

subjects without a history of diabetes, presentation of hypoglycaemia was associated with a missed meal. Two of the subjects had also ingested alcohol, while one subject had sustained a cerebrovascular injury. Another subject without a history of diabetes 'was currently on Metoprolol. In two further subjects no precipitating cause could be identified.

Laboratory confirmation of alcohol ingestion was seen in only five of the 14 insulindependent and two of the four non-insulin-dependent diabetic subjects who had a history of recent alcohol intake (Table 3).

Major clinical manifestations of hypoglycaemia (fits or coma) were documented in $49 \%$ of insulin-dependent diabetic subjects and in $63 \%$ of the non-diabetic subjects 
Table 3 Number of subjects with laboratory confirmation of alcohol consumption

\begin{tabular}{llll}
\hline & $\begin{array}{l}\text { Confirmed } \\
(>10 \mathrm{mg} \%)\end{array}$ & $\begin{array}{l}\text { Not confirmed } \\
(<10 \mathrm{mg} \%)\end{array}$ & Not known \\
\hline $\begin{array}{l}\text { Insulin-dependent } \\
\text { diabetic }(n=14)\end{array}$ & 5 & 8 & $1^{*}$ \\
$\begin{array}{l}\text { Non-insulin-dependent } \\
\text { diabetic }(n=1)\end{array}$ & 2 & 1 & $1 *$ \\
$\begin{array}{l}\text { Non-diabetic } \\
\text { subjects }(n=4)\end{array}$ & - & 1 & \\
& 7 & 10 & - \\
\hline
\end{tabular}

*Test not done due to hepatitis $B$ positive.

Table 4 Frequency of hypoglycaemic symptoms

\begin{tabular}{lll}
\hline Total $(n=86)$ & $\begin{array}{l}\text { Fits and coma } \\
42(49 \%)\end{array}$ & $\begin{array}{l}\text { Minor symptoms* } \\
44(51 \%)\end{array}$ \\
\hline $\begin{array}{l}\text { Insulin-dependent } \\
\text { diabetic }(n=75)\end{array}$ & $37(49 \%)$ & $38(51 \%)$ \\
$\begin{array}{l}\text { Non-insulin-dependent } \\
\text { diabetic }(n=3)\end{array}$ & 0 & $3(100 \%)$ \\
Non-diabetic $(n=8)$ & $5(63 \%)$ & $3(37 \%)$
\end{tabular}

* = Drowsy, confused, sweating, headache, difficulty in walking.

(Table 4). All subjects with non-insulin-dependent diabetes in this study presented $\overrightarrow{\vec{\partial}}$ with only minor symptoms (Table 4).

While hospital admission was necessary for two non-insulin-dependent and five nondiabetic subjects, only four of the 61 insulin-dependent diabetic subjects required admission. The remainder of the patients were able to be discharged home following treatment. After the hypoglycaemic episode, seven insulin-dependent diabetic subjects attended their general practitioner, two were seen in the diabetic clinic, and four were reviewed by the diabetic liaison sister.

\section{DISCUSSION}

This study has shown the high frequency of a missed meal as a precipitating cause of $\mathcal{W}_{\tilde{W}}$ hypoglycaemia. This was observed in $52 \%$ of all cases and in $54 \%$ of subjects with insulin-dependent diabetes. It would thus appear obvious that dietary education could $\varrho$ potentially ameliorate this situation. Furthermore, while a total of 86 hypoglycaemic $\stackrel{\oplus}{\oplus}$ episodes over the 12 -month period were documented, this accounted for $0 \cdot 18 \%$ of all 
new cases presenting to the $\mathrm{A} \& \mathrm{E}$ department, and thus comprised only a small part of the total workload. Previous reports describe greater numbers requiring hospital treatment for hypoglycaemia over a 12-month period (Potter et al., 1982; Fischer et al., 1986; Goldgewicht et al., 1983). Both the number of cases and the precipitating factors for hypoglycaemia in this inner-city study may have been influenced by one of several of the following demographic features; the increase in alcohol abuse and the special problems of tourists, unemployment and homelessness (Cummins et al., 1981). The numbers of cases may have been artificially low compared to rural areas due to the relative proximity of several large London hospitals with $A \& E$ departments and diabetic clinics.

In this study hypoglycaemia occurred more frequently in the summer months. This may be due to the tendency of consuming lighter meals and taking more exercise in the summer. Alterations in insulin absorption due to temperature may also be a contributing factor.

While the oldest diabetic subject in this study was 53 years old, it is well established that hypoglycaemia can occur in the elderly and potentially with all forms of insulin therapy.

Previous reports have attributed a change in insulin dose in up to $39 \%$ of cases (Tchobrousky et al., 1981; Potter et al., 1982; Fischer et al., 1986). In this study an increase in insulin was identified, as a precipitating factor, in $21 \%$ of subjects with IDD.

Renal disease may reduce gluconeogenesis and insulin degradation and thus be associated with hypoglycaemia (Editorial, 1986). However, only one of the insulindependent diabetic subjects in this study had overt renal disease.

The interference with glucoregulatory mechanisms, with masking of hypoglycaemia awareness by $\beta$-adrenergic blocking is well described and may occur with non-selective and beta 1-selective agents (Cryer \& Gerich, 1985). This situation occurred in one subject with IDD and one with NIDD.

The hypoglycaemic effect of sulphonylurea therapy is often increased in conjunction with decreased calorie consumption or an increase in dosage or alcohol ingestion. These circumstances were found in individual cases with NIDD. In this study there was no evidence of other adverse drug interactions (for example sulphonamides), where there is displacement of drug from protein binding, to produce an exaggerated hypoglycaemic effect.

Twenty-six per cent of all cases, and 19\% of IDD subjects, had a history of alcohol consumption. A blood alcohol measurement of $>10 \mathrm{mg} \%$ was recorded in only seven of the 17 subjects who had a blood sample taken at the time of presentation (Table 3). The potential social hazard, as well as the adverse drug interaction for the diabetic when driver or pedestrian, with a history of recent alcohol excess, is well documented (Fisher et al., 1985). Alcohol alone may acutely promote hypoglycaemia, usually by inhibiting gluconeogenesis (Marks, 1975). With starvation, the liver is depleted of glycogen, its alternative glucose source. Alcohol may also prime the pancreatic beta cell and exaggerate the pharmacological effect of sulphonylurea agents (Marks, 1975).

The greater number of insulin-dependent diabetic and non-diabetic subjects with a fit or coma as the presenting feature of hypoglycaemia indicated the rapid decline of blood glucose occured without premonitory warning signs (Pramming et al., 1988). A reduction of counter-regulatory hormone response in insulin-dependent diabetes may 
be observed after 5 years of disease duration (Cryer \& Gerich, 1985). This attenuation $\frac{0}{3}$ of warning symptoms obviously increases the chance of severe neuroglycopaenia being $\stackrel{\otimes}{\circ}$ the first clinical manifestation of the hypoglycaemic episode. In this study, recurrent $\vec{F}$ episodes of hypoglycaemia were seen in subjects with the longer duration of diabetes. $\stackrel{\mathcal{O}}{\rightarrow}$ As major clinical manifestations of hypoglycaemia, namely a fit or coma, were seen in $\frac{0}{0}$ $49 \%$ of cases, we would strongly suggest that in all cases of altered consciousness $\frac{\bar{\omega}}{\bar{s}}$ presenting to an A\&E department, a blood glucose estimation should be performed $\stackrel{\mathbb{\Omega}}{\Omega}$ even in the absence of diabetes. While hypoglycaemia is a readily treatable condition, ڤ the inadequately treated patient is at risk of profound long-term sequelae (Auer, 1986). $\vec{\circ}$ In our study a change in insulin dose was seen in only a few cases of insulin-treated patients but dietary factors such as a missed meal and/or alcohol ingestion had a greater $\omega_{\sigma}$ influence on overall case presentation. All doctors should also be aware of the potential $\frac{\Phi}{3}$ for the patient to plead that hypoglycaemia was the reason for diminished responsibility $\frac{3}{6}$. (Maher et al., 1984). The practitioner in accident and emergency is in a position to $\omega$ verify the diagnosis. Greater emphasis is required in education on the regularity of $\vec{\omega}$ meals and caution with alcohol in both diabetic and non-diabetic groups.

\section{REFERENCES}

Auer R. N. (1986) Hypoglycaemic brain damage. Stroke 17, 699-708.

Editorial (1986) Uraemic hypoglycaemia. Lancet 1, 660-1.

Cryer P. E. \& Gerich J. E. (1985) Glucose counter-regulation, hypoglycaemia and intensive insulin therapy diabetes mellitus. New England Fournal of Medicine, 313, 232-41.

Cummins R. O., Shaper A. G., Walker M. \& Wale C. J. (1981) Smoking and drinking by middle-aged British men; effects of social class and town residence. British Medical fournal 283, 1497-505.

Fischer K. F., Lees J. A. \& Newman J. H. (1986) Hypoglycaemia in hospitalized patients-causes and $\stackrel{\circ}{\circ}$ outcomes. New England fournal of Medicine 315, 1245-50.

Fisher B. M., Storer A. M. \& Frier B. M. (1985) Diabetes, driving and the general practitioner. British Medical fournal 291, 181-2.

Goldgewicht C., Slana G., Papoz L. \& Tchobroutsky G. (1983) Hypoglycaemic reactions in 172 Type I (insulin-dependent) diabetic patients. Diabetologia 24, 95-9.

Maher G., Pearson J. \& Frier B. M. (1984) Diabetes mellitus and criminal responsibility. Medicine, Science and the Law 24, 95-101.

Marks V. (1975) Alcohol and changes in body constituents; glucose and hormones. Proceedings of the Royal Society of Medicine 68, 377-80.

Potter J., Clarke P., Gale E. A. M., Dawe S. H. \& Tattersall R. B. (1982) Insulin-induced hypoglycaemia in an accident and emergency department: the tip of the iceberg? British Medical fournal 285, 1180-2.

Pramming S., Thorsteinseen B., Stigsby B. \& Binder C. (1988) Glycaemia threshold for changes in $\frac{0}{3}$ electrocephalograms during hypoglycaemia in patients with insulin-dependent diabetes. 'British Medical $D$ Fournal 296, 665-7.

Tchobrousky G., Goldgewicht C., Papoz L., Weissbrodgt P., Basdevant A. \& Eschwega E. (1981) Hypoglycaemic reactions in 319 IDDM insulin-treated diabetics. Diabetologia 21, 335 (Abstract). 